\title{
Effect of temperature on dicamba degradation using ozone-fly ash combined technology
}

\author{
Lan CHEN
}

Department of Environment Science \& Engineering, North China Electric Power University, Baoding, 071003, China

email: zhedayuquan@126.com

\author{
Keywords: Ozone; Fly Ash; Degradation; Dicamba
}

\begin{abstract}
In order to control pesticide pollution in water environment, ozone-fly ash combined process was studied in laboratory. Dicamba(3,6-Dichloro-2-methoxybenzoic acid) was selected as model pollutant. The reaction temperature was changed to study the degradation efficiency. The experimental results show that fly ash taken from electric field II and III of ESP (No.2 fly ash) is finer than fly ash taken from electric field I of ESP (No.1 fly ash). Dicamba degradation using $\mathrm{O}_{3}$-No.1 fly ash system is faster than dicamba degradation using $\mathrm{O}_{3}$-No.2 fly ash system at same temperature. As the temperature increases, dicamba degradation is accelerated. The degradation can be well fitted by pseudo-first-order kinetics. The pseudo-first-order rate constant increases with temperature increases either in $\mathrm{O}_{3}$-No.1 fly ash system or in $\mathrm{O}_{3}$-No.2 fly ash system. The promote performance of finer No.2 fly ash on ozonation process is better than that of No.1 fly ash.
\end{abstract}

\section{Introduction}

Long-term use of pesticides may lead to water pollution and soil pollution, and further endanger the aquatic ecosystems and soil ecosystems, which threatens human health through the food chain. Dicamba (3,6-dichloro-2-methoxybenzoic acid), one of the chlorinated herbicides, is used to control broadleaf weeds in corn field and wheat field or used for lawn maintenance. Because of its high solubility and low volatility, dicamba has high potential to be leached from soil into water body. Dicamba contamination has occasionally been found in surface water and ground water [1]. Dicamba is harmful to aquatic organism, and has potential genotoxicity [2, 3]. Therefore, the control of dicamba pollution has been paid more and more attention. Maya-Treviño et al. investigated the degradation of dicamba and 2,4-D herbicides using simulated solar light with $\mathrm{ZnO}-\mathrm{Fe}_{2} \mathrm{O}_{3}$ catalyst [4]. They reported that complete degradation of both herbicides (initial concentration $10 \mathrm{mg} \cdot \mathrm{L}^{-1}$ ) was attained after $300 \mathrm{~min}$ using $0.5 \mathrm{~g} \cdot \mathrm{L}^{-1}$ of catalyst loading. Chu et al. found that the direct photolysis and the photocatalytic process can effectively degrade dicamba in $\mathrm{TiO}_{2}$ suspensions with and without the use of $\mathrm{H}_{2} \mathrm{O}_{2}$ [5].

Fly ash is one of the residues generated in thermal power plant. The disorder stack of fly ash can lead to the contamination of soil and water. Recently, the reuse of fly ash is becoming an interest area. Its current and potential applications include usage in the soil amelioration, construction industry, ceramic industry, zeolite synthesis, catalysis, depth separation, etc [6]. It is rarely reported that the combined technology of $\mathrm{O}_{3}$ and fly ash. Ozonation is an effective method to degrade dyes [7, 8], pesticides [9, 10], and landfill leachates [11]. Previous studies reported that the combination of ozonation with other techniques such as $\mathrm{O}_{3} / \mathrm{UV}, \mathrm{O}_{3} / \mathrm{US}$, catalytic ozonation and $\mathrm{O}_{3} / \mathrm{H}_{2} \mathrm{O}_{2}$ can be proved more efficient. In our previous study [12], the promotion of fly ash on ozonation of dicamba was proved to be very obvious. In this paper, two kinds of fly ash was taken from one power plant. The aim of this paper is to study the effect of temperature on $\mathrm{O}_{3}$-fly ash combined process in aqueous solution.

\section{Experimental Parts}

The model pollutant used in laboratory was dicamba(Purity $>95 \%$, purchased from Shanghai 
Yuanye Bio-Technology Co., Ltd.). Two kinds of fly ash used in this study were taken from a certain power plant of Hebei province. Fly ash collected from electric field I of Electrostatic Precipitator(ESP) was named No.1 fly ash. Fly ash collected from electric field II and III of ESP was named No.2 fly ash. The reaction solutions were prepared with deionized water without addition of $\mathrm{pH}$ adjusting agents.

The experimental system consisted of a bubble reactor, an ozone generator and some pipes. The reactor was placed in a temperature-controlled water bath. Mixed gas of ozone and oxygen was produce by the ozone generator(3S-A5, Beijing Tonglin High-tech Technology Co., Ltd. China) using pure oxygen source as feed gas. The solution volume in reactor was $900 \mathrm{~mL}$. A certain amount of fly ash was added into the reaction solution and mixed well before gas introducing. The mixed gas was fed into reactor after being adjusted to desirable gas flow rate using rotameter. Samples were withdrawn from the reactor periodically, filtered through $0.22 \mu \mathrm{m}$ filter membrane, and then analyzed using HPLC.

If there is no particular declaration, the experimental conditions were as follows: the dosage of fly ash was $1.0 \mathrm{~g}$ for $\mathrm{O}_{3}$-No.1 fly ash system, $0.5 \mathrm{~g}$ for $\mathrm{O}_{3}-\mathrm{No}_{2} 2$ fly ash system; the ozone production ratio was $70 \%$; the gas flow was $1 \mathrm{~L} \cdot \mathrm{min}^{-1}$; the $\mathrm{pH}$ level of solution was initial $\mathrm{pH}$ value without any $\mathrm{pH}$ adjustor; the initial concentration of dicamba was $100 \mathrm{mg} \cdot \mathrm{L}^{-1}$.

The concentration of dicamba was determined by HPLC (LUMTECH, Lumiere Tech. Ltd. China). The mobile phase was a mixture of methanol and water (volume ratio of 65:35) (pH value was adjusted using phosphoric acid). The flow rate of mobile phase was $1 \mathrm{~mL} \cdot \mathrm{min}^{-1}$. The injection volume was $20 \mu \mathrm{L}$, and the detection wavelength was $230 \mathrm{~nm}$.

\section{Results and Discussion}

Particle diameter of fly ash Two kinds of fly ash used in this study were taken from a power plant of Hebei province. Fly ash collected from electric field I of ESP was named No.1 fly ash. Fly ash collected from electric field II and III of ESP was named No.2 fly ash. Two kinds of fly ash were screened and statistically analyzed (Fig.1). The average diameter of particle was calculated by mathematical average between up and down screen meshes.

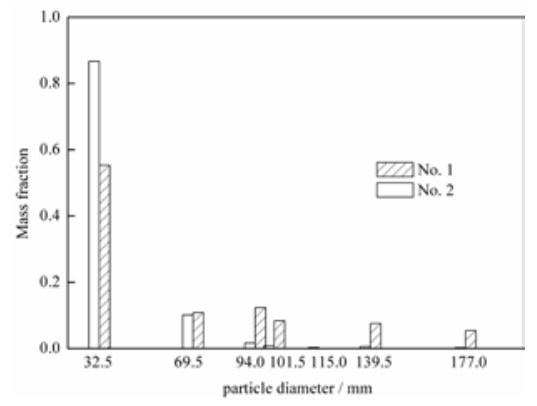

Fig. 1 Screening results of two kinds of fly ash

From Fig. 1, it can be seen that most of the fly ash are concentrated in $32.5 \mu \mathrm{m}$ diameter. The mass fraction of $32.5 \mu \mathrm{m}$-diameter-particle reaches $55 \%$ for No.1 fly ash, and the mass fraction of $32.5 \mu \mathrm{m}$-diameter-particle reaches $87 \%$ for No.2 fly ash. No.2 fly ash is finer than No.1 fly ash.

Concentration trend of dicamba Fig. 2 shows the concentration trend of dicamba during ozone-fly ash combined process at different temperature.

From Fig.2, it can be seen that the effect of temperature on dicamba degradation is obvious. At different temperatures, concentrations of dicamba show downward trend at different degrees. Either in $\mathrm{O}_{3}$-No.1 fly ash system or in $\mathrm{O}_{3}$-No.2 fly ash system, with increasing temperature, downward trend of dicamba becomes steeper. At same temperature, dicamba degradation using $\mathrm{O}_{3}-\mathrm{No}_{2}$ fly ash system is faster than dicamba degradation using $\mathrm{O}_{3}$-No.1 fly ash system. 


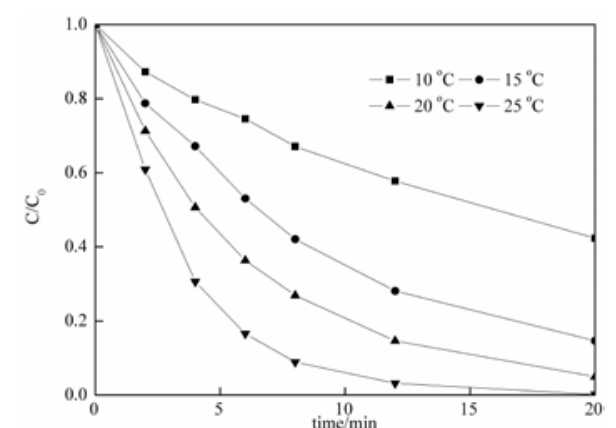

(a) $\mathrm{O}_{3}$-No.1 fly ash system

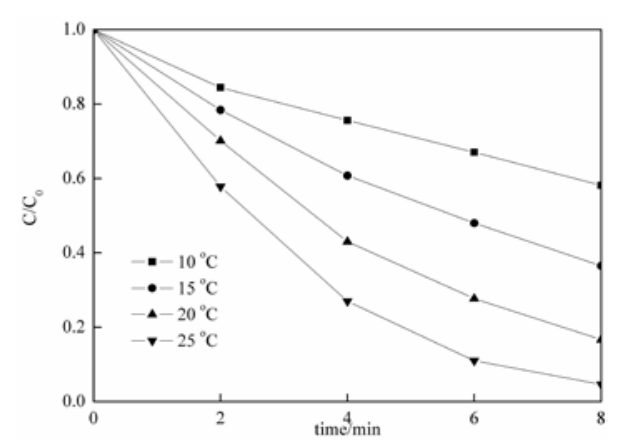

(b) $\mathrm{O}_{3}$-No.2 fly ash system

Fig. 2 Concentration trend of dicamba during degradation process

Kinetic analysis of degradation Fig. 3 shows the fitting result of dicamba concentration using pseudo-first-order kinetics at different temperature using $\mathrm{O}_{3}$-No.1 fly ash system or $\mathrm{O}_{3}$-No.2 fly ash system.

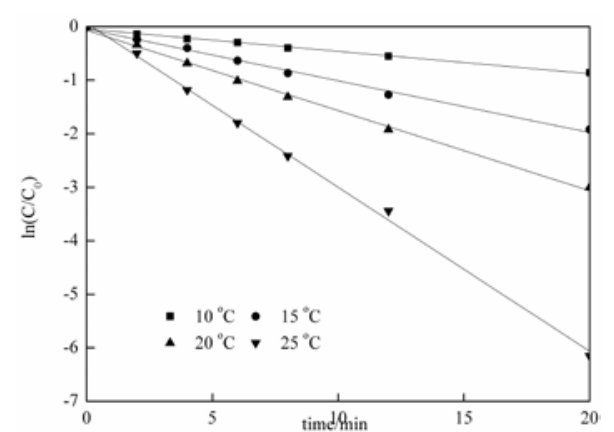

(a) $\mathrm{O}_{3}$-No.1 fly ash system

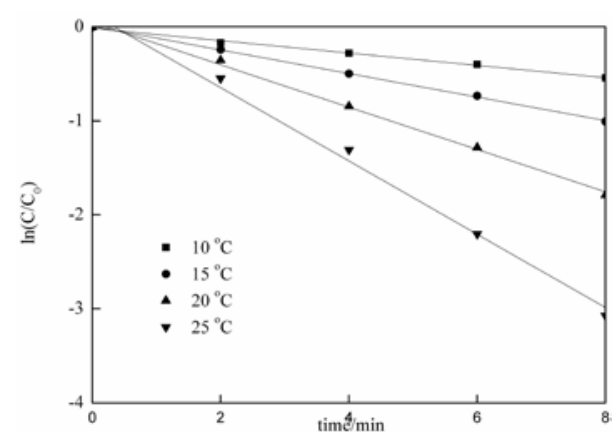

(b) $\mathrm{O}_{3}$-No.2 fly ash system

Fig. 3 Graph of $\ln \left(\mathrm{C} / \mathrm{C}_{0}\right)$ vs. time at different temperatures

From Fig. 3, it can be seen that a good linear is shown between $\ln \left(\mathrm{C} / \mathrm{C}_{0}\right)$ and time $(t)$. Thus it shows that it is feasible and credible to analyze dicamba degradation using pseudo-first-order kinetics at different temperature. The slope of line is the pseudo-first-order rate constant $(k)$. Fig. 4 shows the relationship of $k$ value and temperature(T).

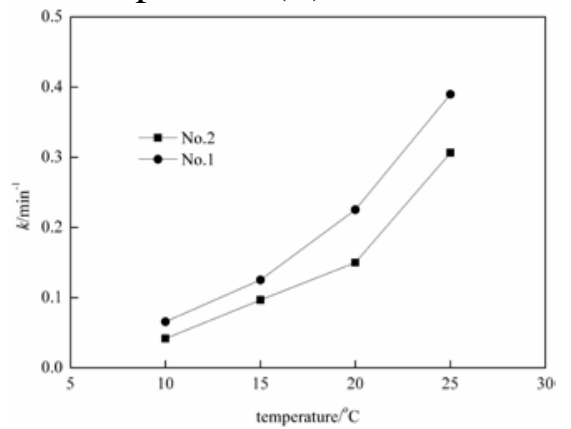

Fig. 4 Graph of $k \sim T$

Either in $\mathrm{O}_{3}$-No.1 fly ash system or in $\mathrm{O}_{3}$-No.2 fly ash system, $k$ value increases with temperature increases. The reaction temperature changes the solubility of ozone. The higher the temperature, the smaller the solubility of ozone, the lower the ozone concentration in aqueous solution is. However, the elevated temperature promotes the decomposition of ozone to produce more hydroxyl radicals, increases the activities of active sites of fly ash surface, and enhances the reaction activity between organics and active substances. Hence, the reaction rate of dicamba and active materials is enhanced with the increased temperature. These $k$ values are analyzed using Arrhenius equation. The apparent activation energy ( $\left.E_{\mathrm{a}}\right)$ of dicamba degradation using $\mathrm{O}_{3}-\mathrm{No.}_{1}$ fly ash system is calculated to be $90.1 \mathrm{~kJ} \cdot \mathrm{mol}^{-1}$, and $E_{\mathrm{a}}$ of dicamba degradation using $\mathrm{O}_{3}-\mathrm{No} .2$ fly ash system is $83.1 \mathrm{~kJ} \cdot \mathrm{mol}^{-1}$. The apparent activation energy of $\mathrm{O}_{3}-\mathrm{No} .1$ fly ash system is larger than that of $\mathrm{O}_{3}$-No.2 fly ash system. Both are less than the apparent activation energy of $\mathrm{O}_{3}$ process. This indicates that the promotion of fly ash on ozone process is accomplished by decreasing the apparent activation energy. The promotion performance of $\mathrm{O}_{3}-\mathrm{No} .2$ fly ash system is more obvious. 


\section{Conclusion}

Reaction temperature can affect strongly on dicamba degradation using $\mathrm{O}_{3}$-fly ash combined process. No.2 fly ash (fly ash taken from electric field II and III of ESP) is finer than No.1 fly ash (fly ash taken from electric field I of ESP). Dicamba degradation using $\mathrm{O}_{3}-\mathrm{No}_{2} 2$ fly ash system is faster than dicamba degradation using $\mathrm{O}_{3}$-No.1 fly ash system at same temperature. The elevated temperature can improve dicamba degradation. The degradation can be well fitted by pseudo-first-order kinetics. The pseudo-first-order rate constant increases with temperature increases either in $\mathrm{O}_{3}$-No.1 fly ash system or in $\mathrm{O}_{3}$-No.2 fly ash system. The apparent activation energy of $\mathrm{O}_{3}$-No.2 fly ash system is less than that of $\mathrm{O}_{3}$-No.1 fly ash system. The promotion performance of No.2 fly ash on $\mathrm{O}_{3}$ degradation process is better than No. 1 fly ash.

\section{Acknowledgement}

This study was financially supported by the Fundamental Research Funds for the Central Universities (No. 2014MS123).

\section{References}

[1] D.B. Donald, A.J. Cessna, E. Sverko, N.E. Glozier. Pesticides in surface drinking water supplies of the northern Great Plains[J], Environ. Health Perspect. 2007, 115: 1183-1191.

[2] C.R. de Arcaute, S. Soloneski, M.L. Larramendy. Evaluation of the genotoxicity of a herbicide formulation containing 3,6-dichloro-2-metoxybenzoic acid (dicamba) in circulating bloodcells of the tropical fish Cnesterodon decemmaculatus[J], Mutation Research. 2014, 773:1-8.

[3] N.V. González, S. Soloneski, M.L. Larramendy. Dicamba-induced genotoxicity in Chinese hamster ovary (CHO) cells is prevented by vitamin E[J], Journal of Hazardous Materials. 2009, 163: 337-343.

[4] M.L. Maya-Treviño, J.L. Guzmán-Mar, L. Hinojosa-Reyes, N.A. Ramos-Delgado, M.I. Maldonado, and A. Hernández-Ramírez. Activity of the $\mathrm{ZnO}-\mathrm{Fe}_{2} \mathrm{O}_{3}$ catalyst on the degradation of Dicamba and 2,4-D herbicides using simulated solar light[J], Ceramics International. 2014, 40: 8701-8708.

[5] W. Chu, and C.C. Wong. The photocatalytic degradation of dicamba in $\mathrm{TiO}_{2}$ suspensions with the help of hydrogen peroxide by different near UV irradiations[J], Water Research. Vol 2004, 38: 1037-1043.

[6] Z.T. Yao, X.S. Ji, P.K. Sarker, J.H. Tang, L.Q. Ge, M.S. Xia, Y.Q. Xi. A comprehensive review on the applications of coal fly ash[J], Earth-Science Reviews. 2015, 141: 105-121.

[7] W. Zhao, Q. Liao, J. Zhang, Y. Yang, J. Dai, D. Zhao. Oxidation of Cationic Red X-GRL by ozonation combined with UV radiation in aqueous solution: Degradation, kinetics, and modeling[J], Chemical Engineering Journal, 2011, 171: 628-639.

[8] Z. He, L. Lin, S. Song, M. Xia, L. Xu, H. Ying, J. Chen. Mineralization of C.I. Reactive Blue 19 by ozonation combined with sonolysis[J], Separation and Purification Technology, 2008, 1 62: 376-381.

[9] Y. Quan, L. Chen, Y. Song, D, Zou. Effect Parameters of Ozonation of Dicamba in Aqueous Solution[J], Advanced Materials Research. 2013, 750-752: 1258-1261.

[10] L. Chen, Y. Quan, Z. Li. Kinetics analysis of ozone degradating 2,4-D pollutant in soil[J], CIESC Journal. 2014, 65(8): 3255-3260(in Chinese).

[11] T. Poznyak, G. Luis Bautista, I. Chaírez, R. Ivan Córdova, L. Elvira Ríos. Decomposition of toxic pollutants in landfill leachate by ozone after coagulation treatment[J], Journal of Hazardous Materials. 2008, 152: 1108-1114.

[12] L. Chen, Y.Y. Wang. Degradation of Dicamba in Aqueous Solution Using Ozonation Assisted by Fly Ash[C]. 2015 International Conference on Electrical Engineering and Mechanical Automation (ICEEMA 2015), Wuhan. 